\title{
Lithological indicators of loess sedimentation of SW Poland
}

\author{
Marcin Krawczyk, Kamila Ryzner, Jacek Skurzyński, Zdzisław Jary \\ University of Wroclaw, Institute of Geography and Regional Development, 1 Uniwersytecki Sqr., 50-137 \\ Wroclaw, Poland \\ marcin.krawczyk@uwr.edu.pl,kamila.ryzner@uwr.edu.pl,jacek.skurzynski@uwr.edu.pl, \\ zdzislaw.jary@uwr.edu.pl
}

Received: $25^{\text {th }}$ April, 2017 Accepted: $19^{\text {th }}$ November, 2017

\begin{abstract}
High-resolution grain-size investigations were carried out in two SW Polish loess sections: Biały Kościół (Niemcza-Strzelin Hills) and Zaprężyn (Trzebnica Hills). Each sequence was sampled by using the same methodology and samples were taken at 5 centimeters intervals. The particle size distribution was obtained with a Mastersizer 2000 laser, used for diffraction methods. From the obtained results the basic parameters and grain size indicators were calculated: Mz, Grain Size Index ratio, U-ratio and the percentage content of clay $(<4 \mu \mathrm{m})$ and sand $(>63 \mu \mathrm{m})$. Both loess- soil sequences are composed of interfluve and slope loess facies and consist of five litho-pedostratigraphic units developed during the Late Pleistocene and Holocene: two loess units L1LL1, L1LL2 and three polygenetic fossil soils sets S0, S1 and L1SS1. The distance between these two profiles is about $60 \mathrm{~km}$. Zaprężyn, as a section located more to the north, has almost no lower younger loess and higher level of weathering which could be related to proximity of this site to the Ice Sheet margin. The climate here was more extreme and harsh. What is more,the difference in development of soil L1SS1 can be observed: while in Biały Kościół pedogenesis process was slower and less disturbed than in Zaprężyn. The upper part of L1SS1 in Biały Kościół was deformed by gelifluction, frost heave and other periglacial processes. Mz indicator by the grain-size distribution in these sediments reflects subtle variations in the climatic system. Moreover, in Zaprężyn the content of sand fraction is higher than in Biały Kościół what can be the evidence of short episodes of strong winds during cold period of sedimentation. The aim of this paper is to compare two loess profiles by their stratigraphical and lithological similarities which are result of climate conditions and features of surrounding environment.
\end{abstract}

Key words: Silesian Lowland, loess-soil sequences, grain-size indicators, climate change, Last Glaciation

\section{Introduction}

The tendency of climate to relatively sudden changes is one of the most surprising discoveries of the last phase of the Quaternary Research. Loess-soil sequences contain one of the most complete terrestrial record of climate and natural environment changes that took place during the last glaciation. Loess profiles in which there are basically no sedimentary structures indicating wind strength or transport direction of sediment, but that information can be received from the particle size distribution indexes. Every loess region has its own features which cannot be used globally.
However, there are some general similarities showed by many indicators such as the stratigraphy or grain-size variation, which have been observed over different loess regions in Europe and in China.

Loess in Poland occurs in the southern part of the country and it was divided by Maruszczak (1991) into three regions in the Eastern Poland (Lublin, Sandomierz and Kraków uplands) and two in the Western Poland (Karpaty and Sudety forelands). Loess covers of Sudety foreland have smaller thickness and different lithological and stratigaphical features than SE loess areas (Jary, 1996). Those sediments are more similar

\section{OPEN}


to West European loess which reflect more oceanic climate conditions in Pleistocene. (Cegła, 1972; Jersak, 1973; Jary, 2007).

Grain size indicators have been widely used in Chinese and Western European loess as a proxy mainly to reconstruct wind speed, dust source distance and past climatic variations, (Liu, 1985; Vandenberghe et al., 1997; Vandenberghe and Nugteren, 2001; Rousseau et al., 2002; Antoine et al., 2009). Characteristics of loess grain size are an important part of many works of polish loess researchers (Cegła, 1965, 1972; Jersak, 1965, 1973; Jary, 1996, 2007; Dwucet, 1993, 1999). They were mostly based on the Folk and Ward methods (1957). However, nowadays less complicated grain size proxies are used. It can be assumed that the variability of basic lithological features of properly selected loess sequences in Poland, analyzed in the vertical profile with the use of high- resolution sampling for laboratory analyzes, and precise, repeatable techniques of markings grain size composition, provide new, more detailed data about climate change loess environments sedimentation (Jary, 2007).

Within this context, and in order to obtain a detailed lithological characteristic of loess sedimentation of SW Poland, the authors decided to focus on two main Late Pleniglacial loess sequences: Biały Kościół and Zaprężyn, where complex stratigraphy have been identified (Jary and Ciszek, 2004; Jary, 2007; Moska et al., 2012).

The aim of the study is to compare two loess profiles of Silesian Lowland with respect to lithology and stratigraphy based on selected lithological indicators and to find specific markers to compare them more regionally.

\section{Study area}

Study area is located within the Silesian Lowland which forms a vast plain between the Sudety foreland and the Sudety mountains from the southwest, Silesian Rampart from the north and the Silesian Upland on the east. The main feature of Silesian Lowland relief is its mosaic pattern. The characteristic feature of climate is relatively high average annual temperature (Wrocław $8,7^{\circ} \mathrm{C}$ ), short winter, early, moist spring and warm summer (Sobik, 2005). These properties are connected with the existence ofthe mountain barrier of the Sudety on the south-west (Kondracki, 1981).

Loess in Silesian Lowland occurs in several isolated patches (Fig. 1), which differ from each other with thickness, stratigraphic sequence and basic physico-mechanical properties (Cegła, 1972; Kida, 1983; Jary, 1996; Jary et al., 2002). Loess in Silesian Lowland has been investigated for a long time. First by German and then by polish researchers. The German authors (Tietze, 1910; Czajka, 1931; Meister, 1935; Schwarzbach, 1942) focused on Trzebnica and Głogów regions covered by loess and loesslike loam deposits. Also Tietze (1919) and Behr (1921) described similar deposits known as Oława valley loess near Niemcza -Strzelin Hills. In later years Trzebnica sediments were investigated by Walczak (1951), Dylik (1952, 1954), Jahn and Szczepankiewicz (1967), Raczkowski (1969), Rokicki (1952a, b), Jary et al. (1991a), Jary (1991b, 1993, 1996), Jary and Krzyszkowski (1995), Śnieszko (1995) and Traczyk (1996). Strzelin Hills loess and silty sediments were subject of study of Rokicki (1952a), Dylik (1952), Raczkowski (1960, 1969, 1976), Jary and Krzyszkowski (1990). The deposits in Niemcza Hills area were described by Ciszek (1997), Alexandrowicz and Ciszek (1998) and Traczyk (1999).

Investigated sections are located on two main loess areas: Trzebnica Hills and Niemcza-Strzelin Hills. Nowadays there are few exposures that could be used for detailed research. Both sections, chosen in this paper, contain complete record of climate changes during last glaciation. They are characterized by the most compact and thick loess cover in the south-western Poland. 


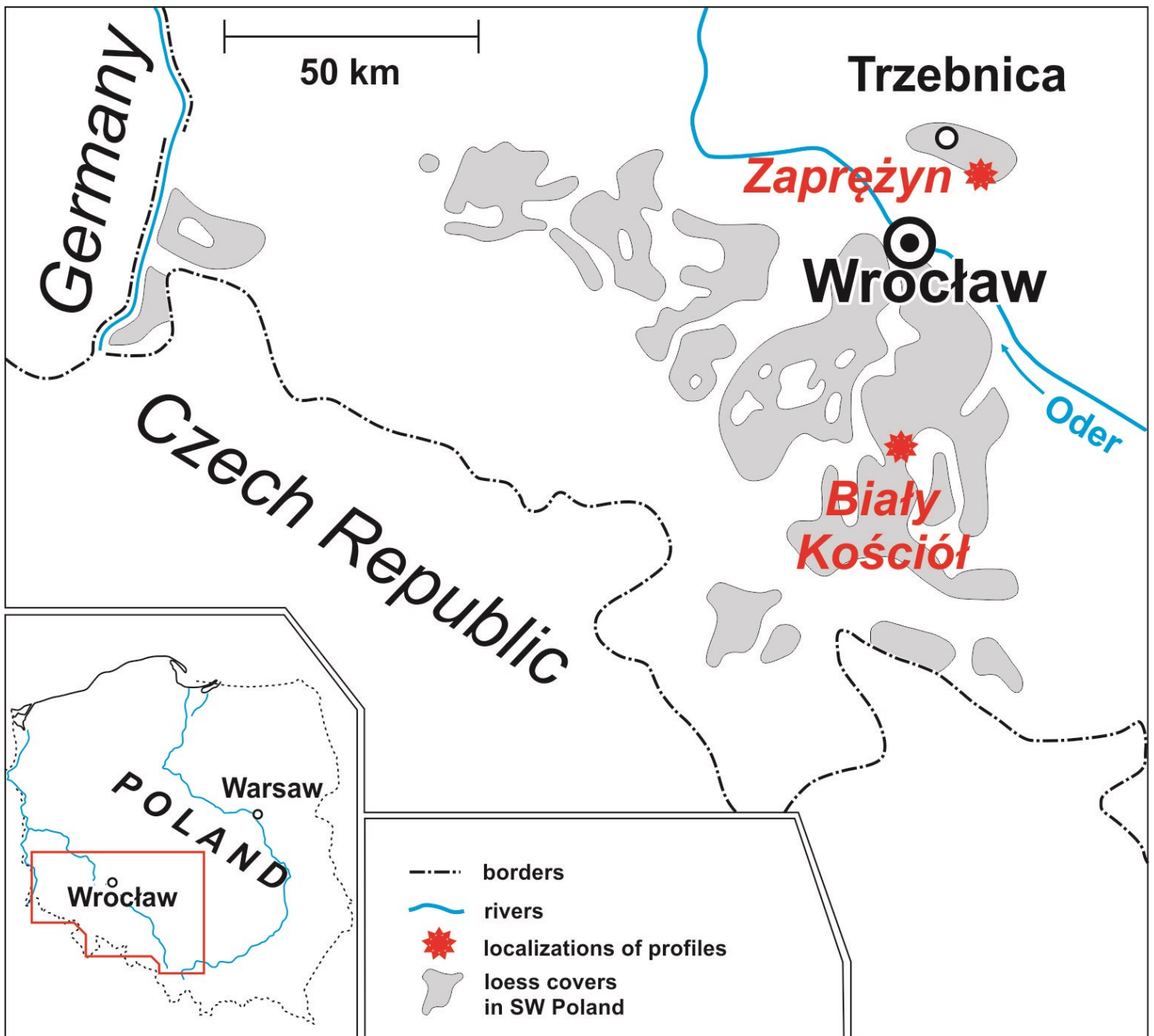

Fig.1. Location of Biały Kościół and Zaprężyn sections in Silesian Lowland, SW Poland (Jary et al., 2016 modificated)

\section{Zaprężyn section (Trzebnica Hills)}

Loess section in Zaprężyn $\left(\lambda=17^{\circ} 12^{\prime} 00^{\prime \prime} \mathrm{E}\right.$, $\varphi=51^{\circ} 14^{\prime} 45^{\prime \prime} \mathrm{N}, 165$ m.a.s.1.) is composed of interfluve and slope loess facies and has $6,5 \mathrm{~m}$. It is situated within the zone of the southern morphological edge of the Trzebnica Hills in an inactive sand quarry located close to the road from Łozina to Węgrów (Fig.2). The area is cut by small denudational valleys of the general N-S course. Loess cover has an average thickness of 4-6 $\mathrm{m}$. The exposure is a result of sand exploitation, which was held here in the 80 s and 90 s of the XX century.

The section was described by Śnieszko (1995) and Szponar (1998) and commented by Maruszczak (2001). Śnieszko (1995) divided the younger loess cover (4-5 $\mathrm{m}$ in thickness) into upper part (rich in calcium carbonates) and lower part with gley horizons. Then the characteristic of Zaprężyn profile has been presented by Szponar (1998 -Kępa-Zaprężyn in this paper). He collected samples from modern and fossil soil and focused on the high content of neutral amino acids. In 2007 Jary presented new results of radiocarbon dating (AMS technique) of Zaprężyn loess section. Charcoals taken from the humic horizon of the fossil forest soil have been dated as $>50 \mathrm{ka} \mathrm{BP}$, humic substances from older tundra-gley soil $26.2 \pm 0.6 \mathrm{ka}$ BP and radiocarbon age of humic substances from younger tundra-gley soil is $18.8 \pm 0.12 \mathrm{ka}$.

\section{OPEN}




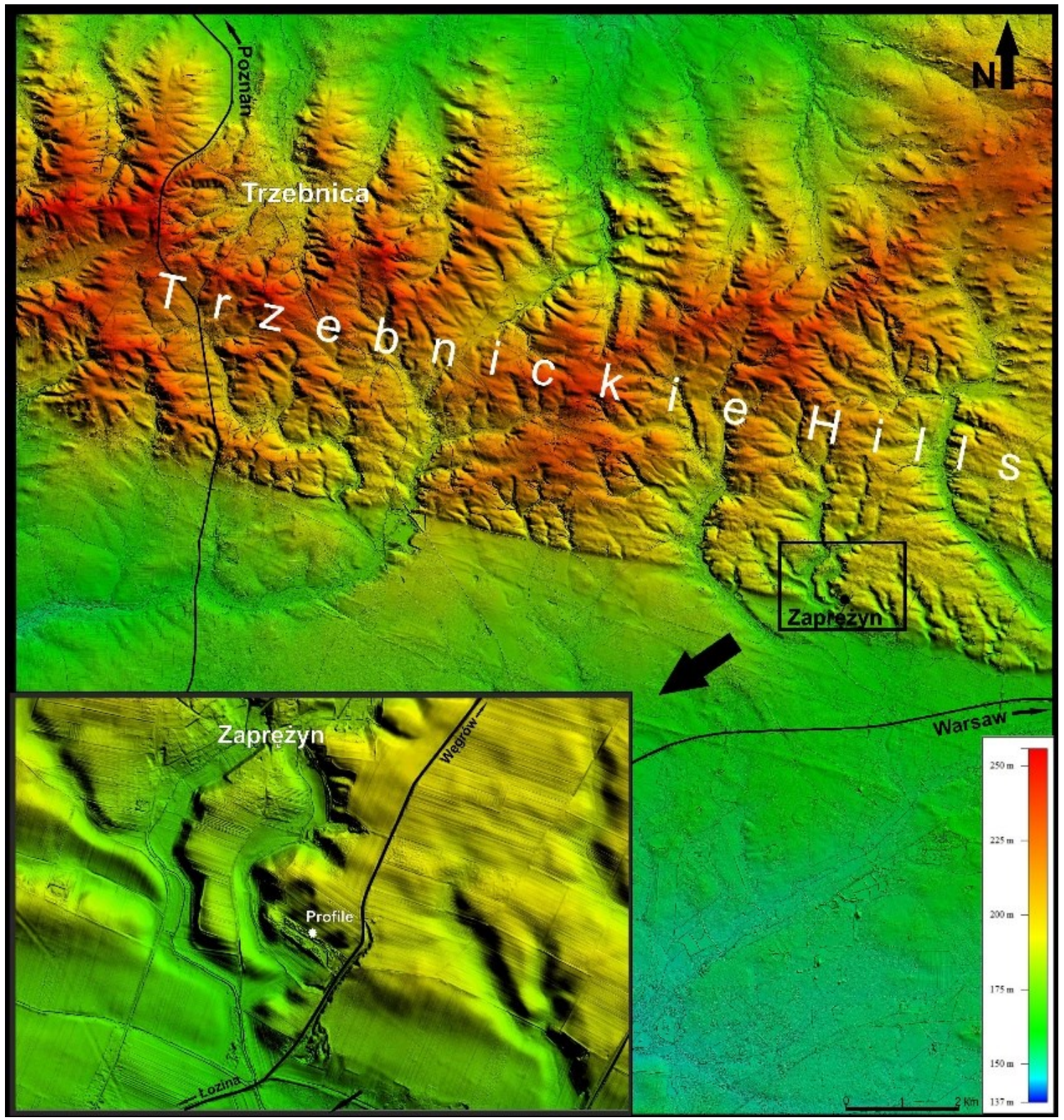

Fig.2. Location of the Zaprężyn site (Jary et al., 2016 - modificated)

Biały Kościót section (Niemcza - Strzelin Hills)

The loess section in the vicinity of the village Biały Kościół $\left(\lambda=17^{\circ} 01\right.$ '30'' $\mathrm{E}, \varphi=$ $50^{\circ} 43^{\prime} 30^{\prime}{ }^{\prime} \mathrm{N}, 193 \mathrm{~m}$.a.s.l) is composed of $9 \mathrm{~m}$ interfluve and slope loessfacies. The loess profile is situated on the west slope of the Oława river valley at an altitude of approximately $185 \mathrm{~m}$ above sea level. It is located in an old clay pit, several meters from the road linking the Strzelin and Henryków (Fig.3).
The loess cover in the surrounding area was previously described by Raczkowski (1960, 1969, 1976) and Ciszek (1997). The complete loess-soil sequence at Biały Kościół has been excavated and characterized by Ciszek et al. (2001).

The results of multidisciplinary research have been published in numerous scientific papers (Jary et al., 2002, 2004; Chlebowski et al., 2004a, 2004b; Fedorowicz et al., 2004; Komar et al., 2004; Fedorowicz, 2005, 2006; Jary, 2007, 2010; Moska et al., 2011, 2012). 


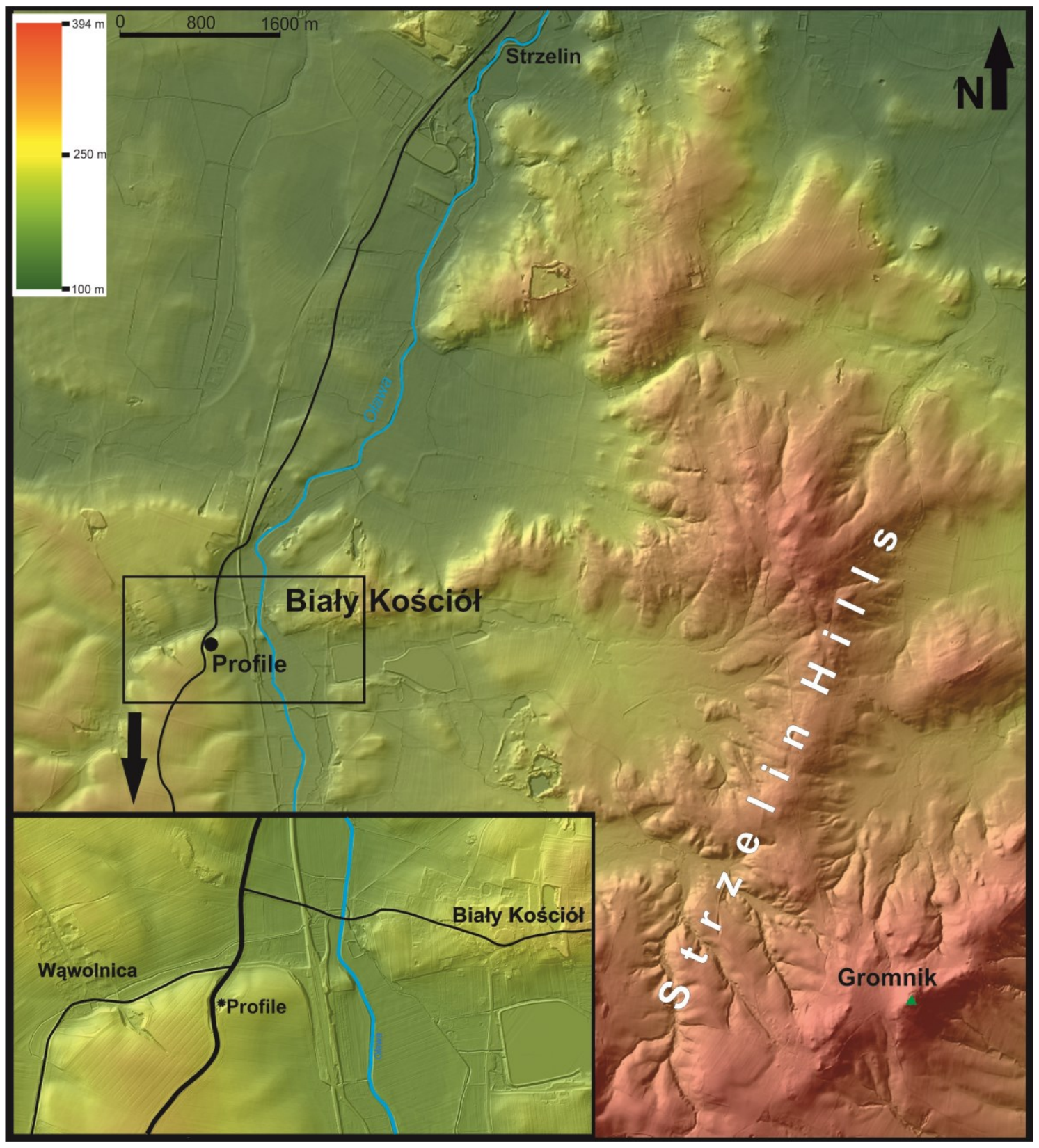

Fig.3. Location of the Biały Kościół site (Jary et al., 2016 - modificated)

\section{Description and stratigraphy}

\section{Zaprężyn}

Detailed description of the deposit succession in the Zaprężyn site is presented on the Fig. 4. This vertical profile was described during filed work conducted in April and May 2011.

Based on the full set of data obtained and on the climatic signature of the various sediment and soil horizons strata, Zaprężyn loess-soil sequence was divided into five lithopedostratigraphic units (Fig.5) developed during the Late Pleistocene and Holocene:

- two loess units (L1LL1, L1LL2);

- three polygenetic fossil soils set (S0, S1 and L1SS1).

In the lower part of the section a set of fossil soils S1 (layers 1-3; Marine Isotopic Stage MIS 5) was formed.It is underlain by the fluvioglacial sand and gravel deposits of the Warta stage with clear evidence of illuviation 
in the upper part. Above, the eluvial horizon Etg (2) and humic horizon (3) occur. In the lower, deformed part of the accumulation horizon, slightly undulating concentrations of charcoals have been preserved.

Above this pedocomplex L1LL2 loess unit occurs (layer 4 and 5, MIS 4). The boundary between S1 and L1LL2 units is sharp.This unit is relatively thin and consists of loess/soil colluvium and calcareous loess. The structure of L1LL2 loess unit is strongly modified by subsequent soil-forming processes associated with the development of the soil L1SS1 lying above.

\section{Lithology}

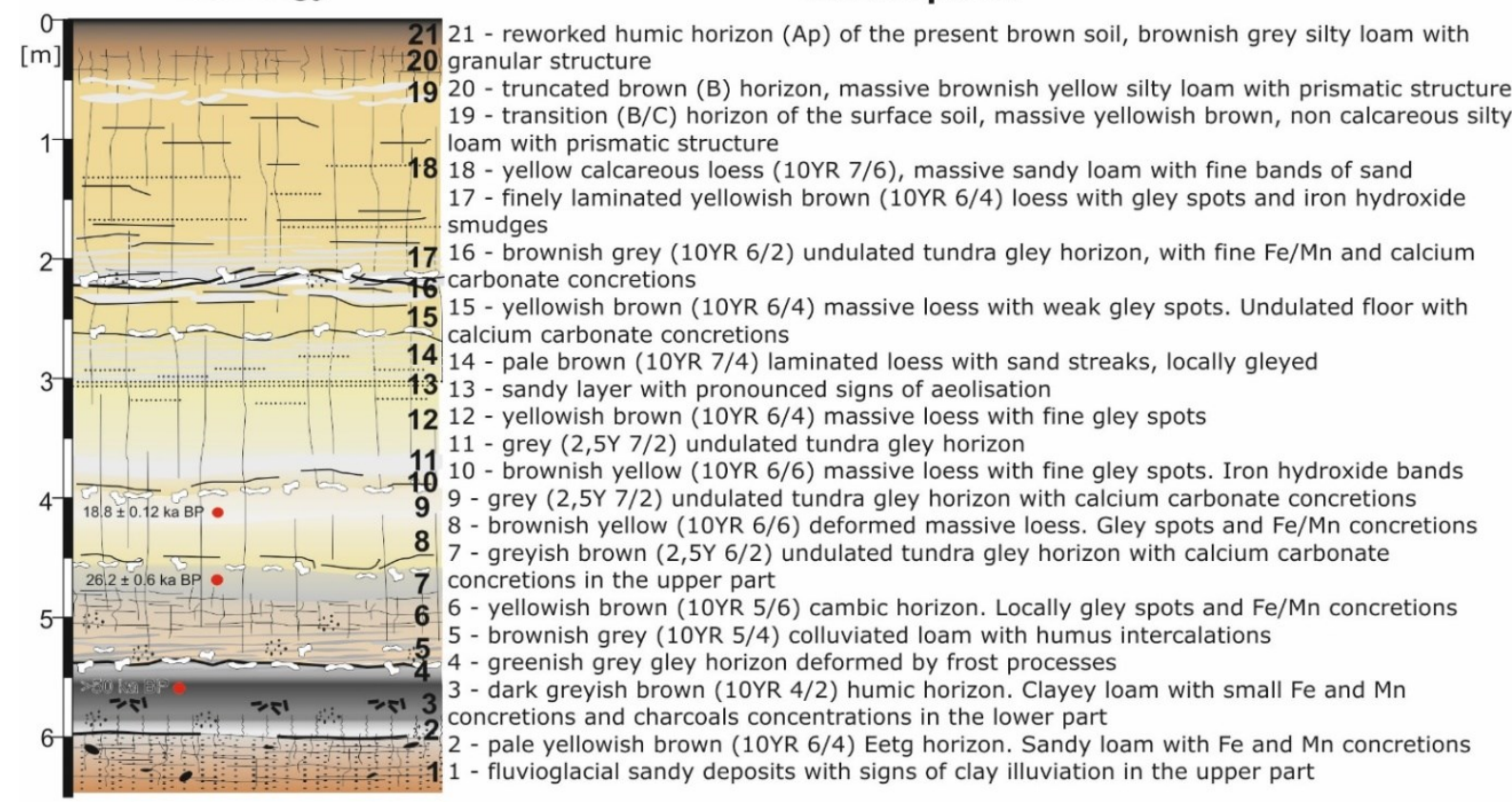

Fig.4. Pedosedimentary sequence and description of the basic units in the Zaprężyn loess section (Jary et al., 2016)

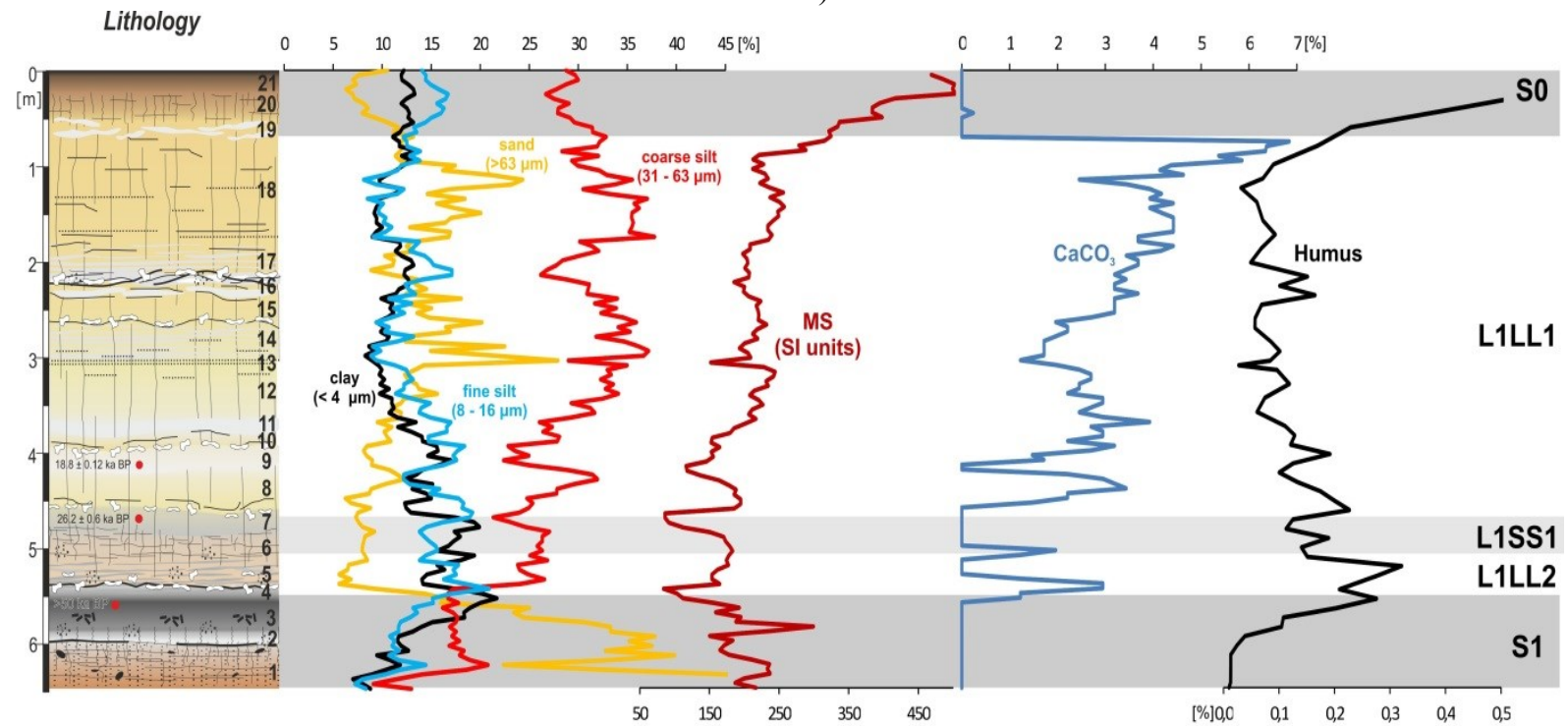

Fig.5. Grain size characteristics, magnetic susceptibility, calcium carbonate and humus content in Zaprężyn loess-soil sequence (S0,L1LL1,L1SS1,L1LL2,S1 - labelling system acc. Kukla and An, 1989, modified by Marković et al., 2015) (detailed description in Jary et al., 2016) 
Pedostratigraphic unit L1SS1 is composed of two genetic horizons: weak cambic horizon (layer 6) and of undulated tundra-gley accumulation horizon (layer 7). Fossil soil set L1SS1 in Zaprężyn was developing most likely in the middle pleniglacial of the last glaciation (MIS 3).

Above L1SS1 unit lays are relatively thick, carbonate less unit L1LL1 (layer 8-18) represented mainly by massive and laminated lithofacies of loess. The characteristic for this loess unit in Zaprężyn is the presence of several gley horizons of different stage of development (eg. layers 9 and 16), often deformed or cut by erosion processes on inclined slope surfaces. The sequence of soil forming and erosional phases are probably connected with sudden climate changes. This could be related to proximity of this site to the Ice Sheet margin. They are usually intercalated by sandy ( $>63 \mu \mathrm{m})$ intercalations mainly in the upper part (Jary et al., 2016).

In the top of L1LL1 loess unit the modern brown soil S0 has been developed (layers 1921). It is relatively thin due to morphological position. It is situated on eroded, cultivated slope surface.

\section{Biaty Kościót}

Detailed specification of the sediment sequence in the Biały Kościół site is presented on the Fig. 6. This profile was described during filed work conducted in November 2008.

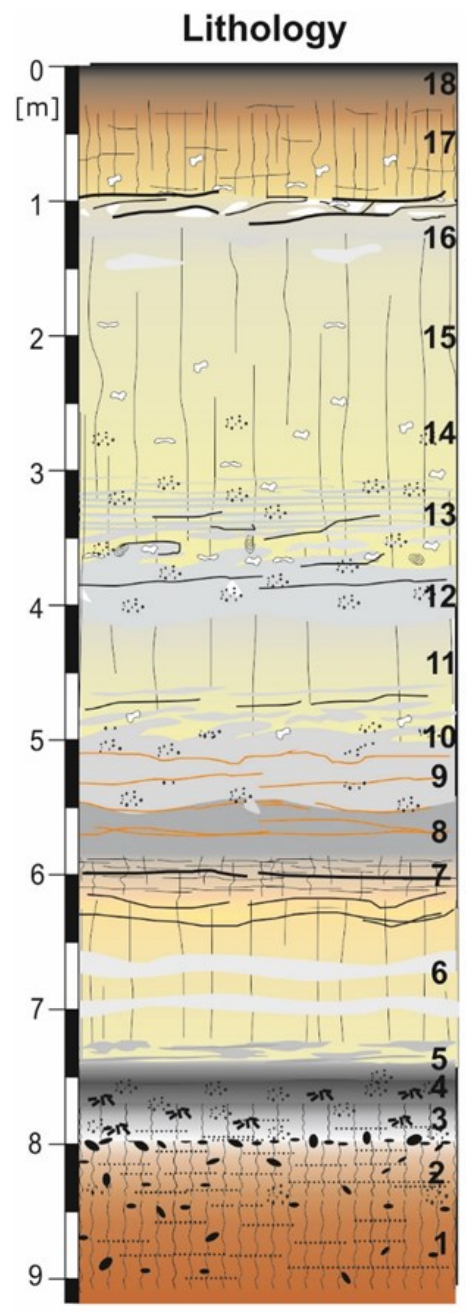

18 - Humic horizon of the surface brown soil, brown grey silty loam with granular structure

717 - B horizon of the surface brown soil, massive brown yellow (10YR 6/6), non calcareous clayey loam with prismatic structure. Calcium carbonate concretions in the bottom part 16 - Yellow-grey loess with grey gley spots. Calcium carbonate and small $\mathrm{Fe} / \mathrm{Mn}$ concretions. Involutions marked by iron hydroxide in the upper part. Iron hydroxide coatings on biopores

1515 - Yellow-brown (10YR 6/4), calcareous massive loess. Blurred gley spots in top part

14 - Massive loess with indistinct fine lamination in the lower part and calcium carbonate concretions

1413 - Laminated yellow-brown loess with grey gley spots and small Fe and $\mathrm{Mn}$ concretions. Streaks and rings of iron hydroxide in the lower part

12 - Light grey horizon with gley spots and streaks. Numerous Fe and $\mathrm{Mn}$ concretions

11 - Pale brown (10YR 7/4) massive loess. Fine smudges of humic material in the base

110 - Deformed humic and loess material redeposited on the slope. Iron hydroxide streaks and gley spots

9 - Brown-yellow (10YR 6/6) geliflucted clayey loam. Numerous

Fe and $\mathrm{Mn}$ concretions in the upper part. Visible marks of gleying

in the lower part

8 - Strongly gleyed greenish-grey horizon deformed by frost heave and gelifluction

7 - Brownish yellow (10YR 6/6) loam with orstein layer/layers in the top. Locally platy structure underlined by iron hydroxides 6 - Yellowish brown (10YR 6/4) massive calcareous loess with three horizons of gleying $(6,15-6,30 \mathrm{~m}, 6,65-6,75 \mathrm{~m}$ and 6,95-

$7,05 \mathrm{~m}$ ). Deformed smudges of humic material in the base 5 - Greenish grey deformed gley horizon

4 - Grayish brown clayey loam with little charcoals and small Fe and $\mathrm{Mn}$ concretions

3 - Very pale brown (10YR 7/3) horizon with small charcoals and $\mathrm{Fe} / \mathrm{Mn}$ concretions

2 - Light brown sandy loam with spots of gley and iron hydroxide. Traces of frost heave processes. Clay cutans and bioturbation structures

1 - Brownish yellow (10YR 6/6) sandy loam with traces of illuviation processes

Fig.6. Pedosedimentary sequence and description of the basic units in the Biały Kościół loess section (Jary et al., 2016) 
Biały Kościół loess-soil sequence consists of five litho-pedostratigraphic units (Fig.7) developed during the Late Pleistocene and Holocene:

- three polygenetic fossil soils/soil sets (S0, S1 and L1SS1)

- two calcareous loess units (L1LL1, L1LL2)

The lowest set of fossil soils S1 (layers 14) has been developed during the last interglacial (Eemian $=$ MIS 5e) and in the early Weichselian (MIS 5d-5a). It consists of thick illuvial Bt horizon developed on heterogeneous sandy-silty substrate, eluvial Etg and humic horizons and a well-marked transition horizon EA with charcoal concentrations.

The characteristic feature of the Biały Kościół loess sequence is the occurrence of thick $(1,5 \mathrm{~m})$ unit of carbonate loess L1LL2 (layers 5-6). This loess was probably deposited during the lower pleniweichselian (MIS 4, Jary, 2007). Some weak tundra-gley horizons can be distinguished within this lithostratigraphic unit which proves climate variability during L1LL2 loess sedimentation.

In the top of loess unit L1LL2 interpleniglacial pedocomplex L1SS1 was developed (layers 7-9). The development of this pedocomplex took place probably in the middle pleniglacial of the last glaciation (MIS 3 ). It consists of superimposed accumulation horizons of tundra-gley soils which cover degraded horizon of the cambic type. It is the only carbonate free soil in the Last Glacial loess sequence at Biały Kościół. The top of L1SS1 soil was deformed by gelifluction, frost heave and other periglacial processes (layer $10)$.

Above the soil L1SS1 there is a thick loess unit L1LL1 (layers 11-16) which was most likely deposited in the upper pleniglacial of the last glaciation (MIS 2). Lithostratigraphic unit L1LL1 shows a significant diversity within

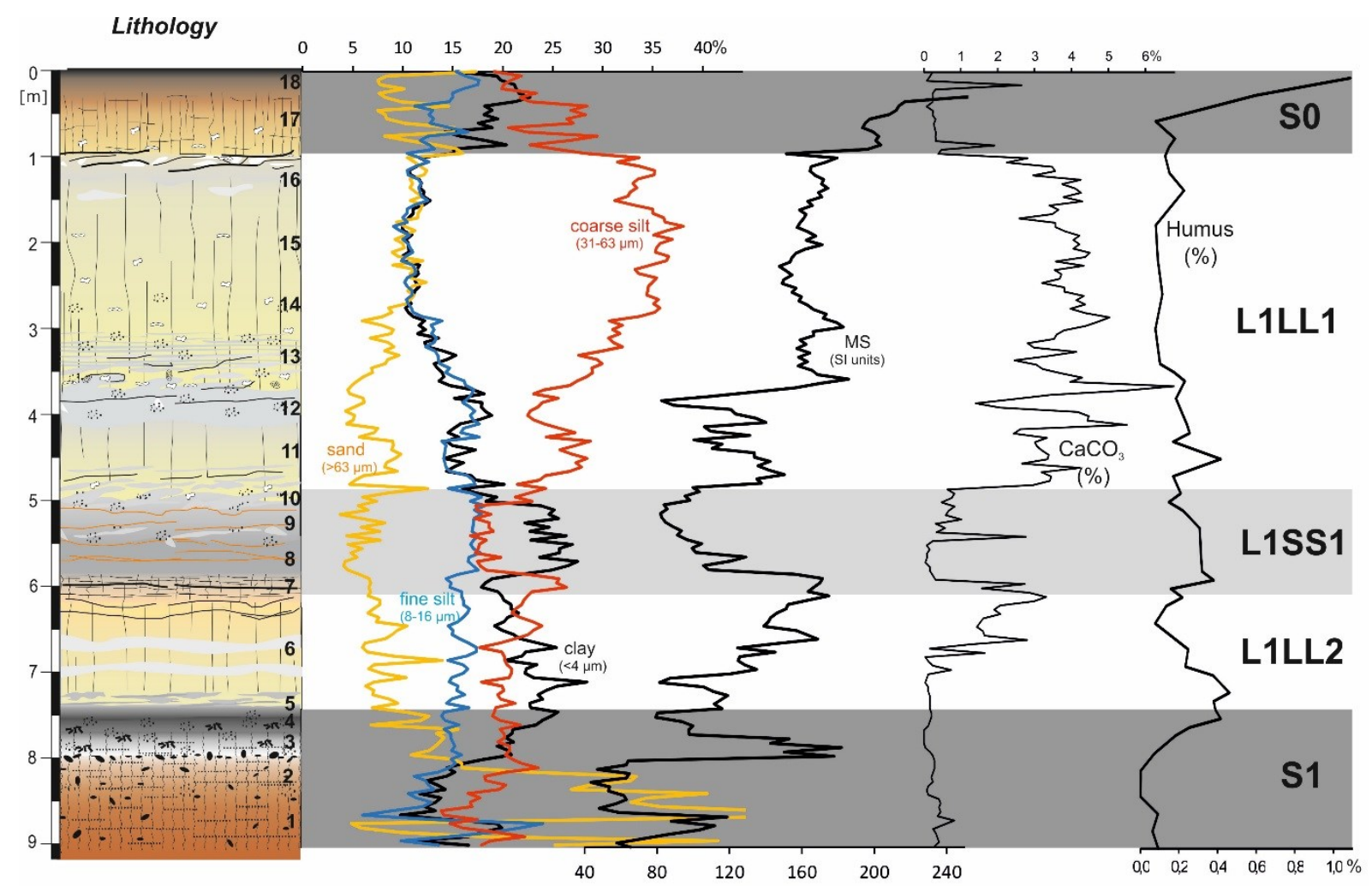

Fig.7. Grain size characteristics, magnetic susceptibility, calcium carbonate and humus content in Biały Kościół loess-soil sequence (S0,L1LL1,L1SS1,L1LL2,S1 - labelling system acc. Kukla and An, 1989, modified by Marković et al., 2015) (detailed description in Jary et al., 2016) 
the section. Noteworthy is weak tundra-gley soil (layer 12), horizons of periglacial deformation (layers 13 and 16) and several horizons of initial gley.

In the top of loess unit L1LL1 a modern brown soil S0 has been developed (layers 17 and 18) (Jary et al., 2016).

\section{Methods}

Research on the both profiles can be divided into two basic stages: field work, which consisted of careful cleaning of the profiles walls, descriptions and sampling for analysis, and laboratory investigations, which allowed to describe a selected physical and chemical properties of the tested materials.

\section{Field work}

Before describing the profiles and sampling the profiles walls were carefully cleaned to picture the freshest material. After that the lithological description was prepared. All of these profiles were sampled in vertical continuous sections at close intervals $(5 \mathrm{~cm})$ and documented with the respect to their sedimentology, paleopedology, and stratigraphy.

\section{Grain Size}

Grain size distributions were determined by using a laser diffractometer Mastersizer 2000 (manufactured by Malvern, England). Before the measurement, organic matterwas removed by $\mathrm{H}_{2} \mathrm{O}_{2}$ and carbonates by $10 \% \mathrm{HCl}$. For better dispersion sodium hexametaphosphate (calgon) was added to the solution before measurement.

Loess grain size proxies are used in paleoenviromental studies to reconstruct dust source distance variations, wind speed or changes of the dust cycle on glacial/interglacial. In the following study two of the most cited indicators was used.
U-ratio indicator is the ratio of the coarse and the medium silt to fine silt fractions (in this study $16-63 \mu \mathrm{m} / 4-16 \mu \mathrm{m})$. This indicator was proposed by Vandenberghe et al. in 1985. U-ratio is used as a proxy for designating warm period (low u-ratio) characterized by weak winds, from cold period with dynamic aeolian environment (strong winds).

The Grain Size Index (GSI) is the ratio of the coarse and medium silt to fine fractions : fine silt and clay (GSI: $20-50 \mu \mathrm{m} /<20 \mu \mathrm{m}$, in this study $16-63 \mu \mathrm{m} /<16 \mu \mathrm{m})$. This indicator was introduced by Rousseau et al. (2002) as an index of wind dynamic and indicator of aeolian dust (Ujvari et al., 2016). The similar index has been previously used by Liu et al. (1989) as a $\mathrm{Kd}$ or loess index (ratio between 10-50 $\mu \mathrm{m}$ and $<2 \mu \mathrm{m})$. The GSI appears to be similar to the U-ratio, but it includes the clay fraction too (Ujvari et al., 2016). Grain Size Index is used to show changes in the productivity of entrainment, transport and deposition of fine vs. coarse dust particles, due to wind speed variations. The high values of GSI indicate increased frequency and strength of dust storms and correspondinglyhigh sedimentation rates (Rousseau et al., 2007).

\section{Magnetic susceptibility}

Magnetic susceptibility measurements of dried soil samples in plastic bags were carried out in the Department of Geological Processes of the Institute of Geology AS CR, v.v.i. in Prague using the KLY-2 Kappabridge (Agico Brno, Czech Republic; magnetic field intensity was $300 \mathrm{~A} \mathrm{~m}^{-1}$, operating frequency $920 \mathrm{~Hz}$, sensitivity $4 \times 10^{-8} \mathrm{SI}$ ) with the error of measurement of $\pm 2 \%$. Raw data on massspecific MS expressed in $\mathrm{m}^{3} / \mathrm{kg} \times 10^{-9}$.

\section{Determination of $\mathrm{CaCO}_{3}$ and organic content}

$\mathrm{CaCO}^{3}$ content was determined based on the analysis of the volume of $\mathrm{CO}^{2}$ produced during the reaction with a weak acid $\mathrm{HCl}$ in the 
Scheibler instrument. Organic carbon content was determined by standard Tiurin method, then translated and presented as the content of humus (Myślińska, 2001).

\section{Results}

\section{Biaty Kościót}

The cumulative grain size curves from averaged samples from five main stratigraphic units are presented in Fig.8. The all curves have their maximum between 4-5 phi (16$63 \mu \mathrm{m})$. The distributions of S0, L1SS1 and L1LL2 curves are similar. In those units the content of fine fractions is increased. The sorting of particles in L1LL1 unit is particularly good and close to Gauss curve with maximum in 4 phi $(31-63 \mu \mathrm{m})$ such a course is typical for Upper Pleistocene loess. The distribution of $\mathrm{S} 1$ curves is more oblate with increase content of coarser fraction which is typical for interglacial soil.

The continuous record of Biały Kosciół loess-soil sequence of grain size variation shows good correlation with stratigraphic horizons observed during field work (Fig. 9).

Content of clay fraction is substantially higher in soil units than in loess horizons. The exception is a L1LL2 horizon where amount of clay is almost as high as clay content in the middle Pleistocene soil. This unit is rich in gley horizons, where higher content of fine material is expected. Increased content of clay is accompanied by the lowest values of grain size indicators and vice versa.

The characteristic feature of Biały Kośció sequence is low content of sand fraction $(>63$ $\mu \mathrm{m})$. In whole profile content of this fraction is less than $20 \%$. Only in the bottom part of S1 soil amount of sand in relatively high, where colluvial material was noted.

$$
\begin{array}{lllll}
\mathrm{SO} & -\mathrm{L} 1 \mathrm{LL} 1 & -\mathrm{L} 1 \mathrm{SS} 1 & -\mathrm{L} 1 \mathrm{LL2} & -\mathrm{S} 1
\end{array}
$$

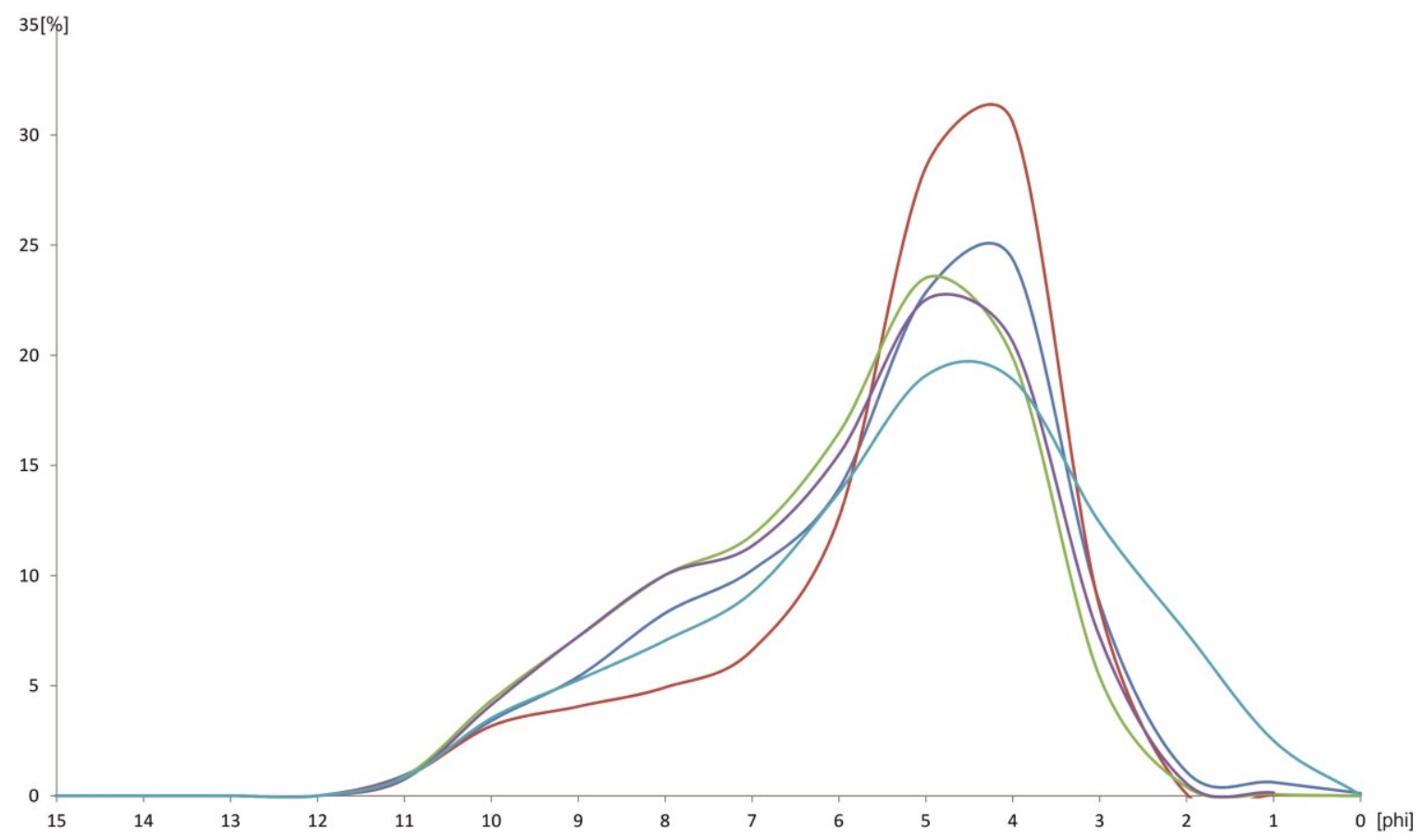

Fig.8. Cumulative grain-size curves from the main stratigraphical units of Biały Kościół 


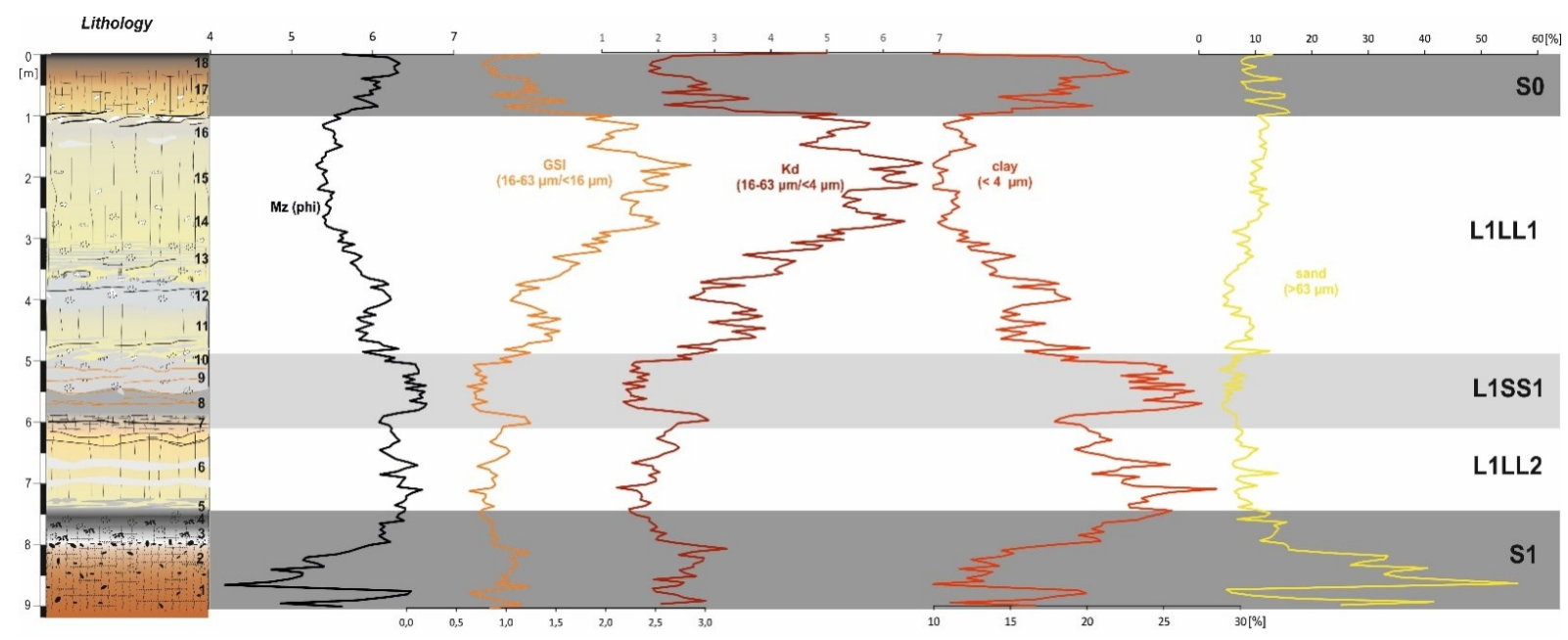

Fig.9. Selected lithological indicators for Biały Kościół profile

The distributions of both grain size indicators are similar. The highest value is in upper part of younger loess unit L1LL1. This part is represented by homogeneous loess, without gley transformations. The progressive coarsening of the loess deposits during period of L1LL1 formation was observed. From the bottom of sequence to L1SS1/L1LL1 boundary values of both indicators do not demonstrate a large variation.

\section{Zaprężyn}

The cumulative grain size curves show that main units of Zaprężyn loess-soil sequence can be divided into three groups (Fig. 10). The S0 and L1LL1 units curves distribution is similar. They have their maximum ( $>30 \%)$ between $4-$ 5 phi like in Biały Kościół. This high content of typical loess fraction $(16-63 \mu \mathrm{m})$ and low amount of clay material in S0 suggests that recent soil was poorly developed and/or eroded by agricultural activity - otherwise than Biały Kościół sequence.

Second group represent distribution of the L1SS1 and L1LL2 units. Their maximum (similar like in first group) is between 4-5 phi but amount of this loess fraction is relatively lower (ca. 25\%). However, the content of finer fraction is increased. It is a normal situation for paleosol units. The higher amount of fine fraction in L1LL2 may be an evidence of the pedogenetic transformation.

The last category is illustrated by the curves of S1 unit. This group of samples is characterized by two well-individualised population of grains: coarse silt (4 phi) and medium sand (1-2 phi; 250-500 $\mu \mathrm{m})$. The highest content of sand fraction is caused by formation of S1 unit on fluvioglacial deposits.

The continuous grain size indicators distributions of the Zaprężyn sequence is illustrated in Fig.11. They demonstrate good correlation between the continues records of the grain size variation and stratigraphic boundaries.

Increased content of clay fraction occurs in both paleosol units. In this places amount of clay material is over $20 \%$. These values are lower than in the previously described soil units from Biały Kościół profile. The average content of clay in L1LL1 unit is about $12 \%$. However, rapid increases of clay value are observed in places where gley horizons were noted. This part of sequence is distinctly different from L1LL1 unit from Biały Kościół. The environmental conditions during the L1LL1 formation were not stable. It is confirmed by the distribution of grain size indicators curves. In spite of that, the values of the indicators for both profiles are similar, 
however, the changes of their distributions are much more rapid and frequent.

The content of sand fraction in Zaprężyn sequence is relatively higher (particularly in the L1LL1 unit) than in previously described loess-soil profile. In two places percentage value of sand exceeds $20 \%$ (units 13 and 18 , Fig.11). The peaks in percentage record of sand are correlated with the highest values of GSI and U-ratio (Fig.11). That could be an indicator of increased strength and dynamics of the winds. The high content ofsand in the lowermost part of the profile is observed too. This part of the profile is composed of fluvioglacial material.

$$
\text { —SO —L1LL1 —L1SS1 —L1LL2 —S1 }
$$

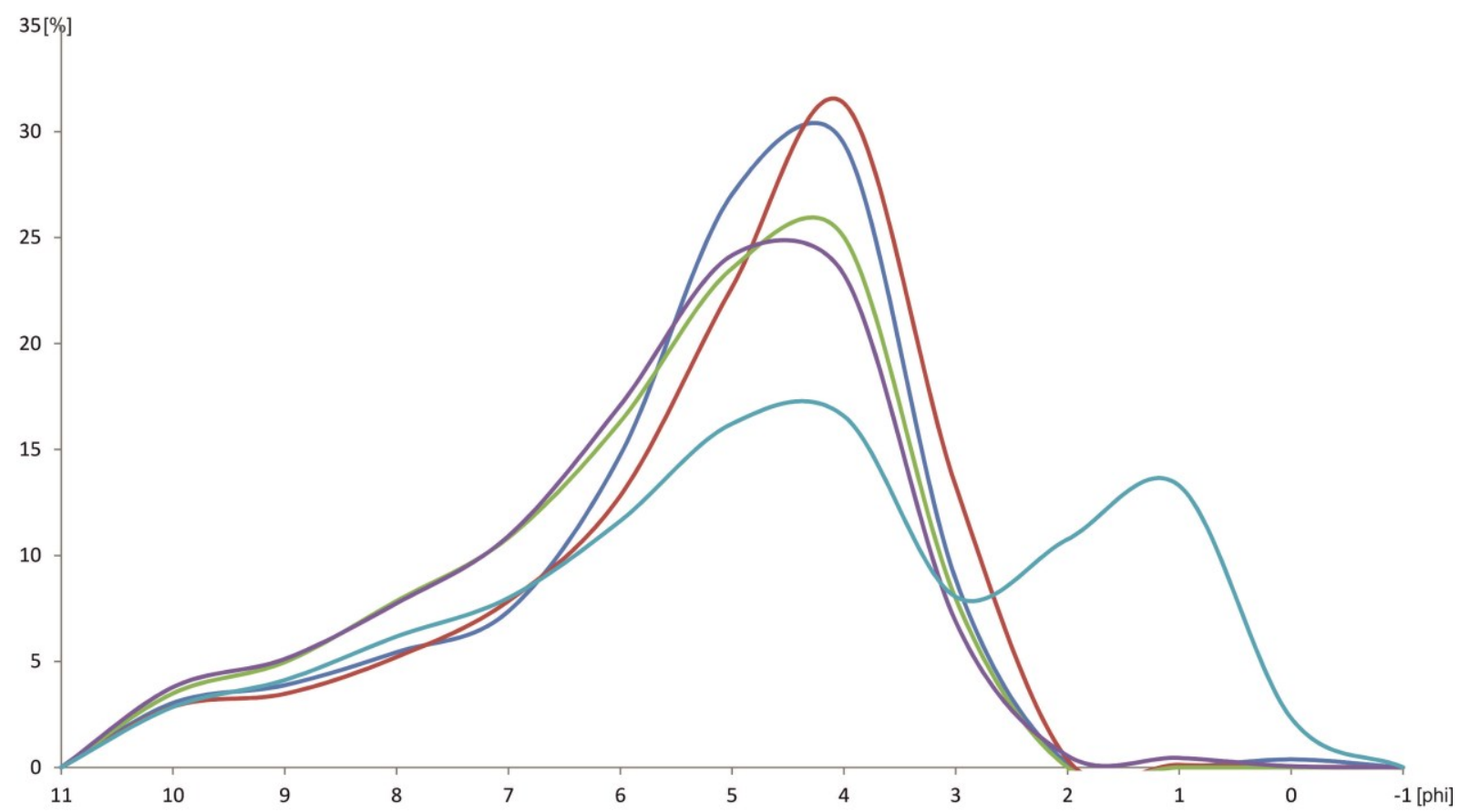

Fig.10. Cumulative grain-size curves from the main stratigraphical units of Zaprężyn

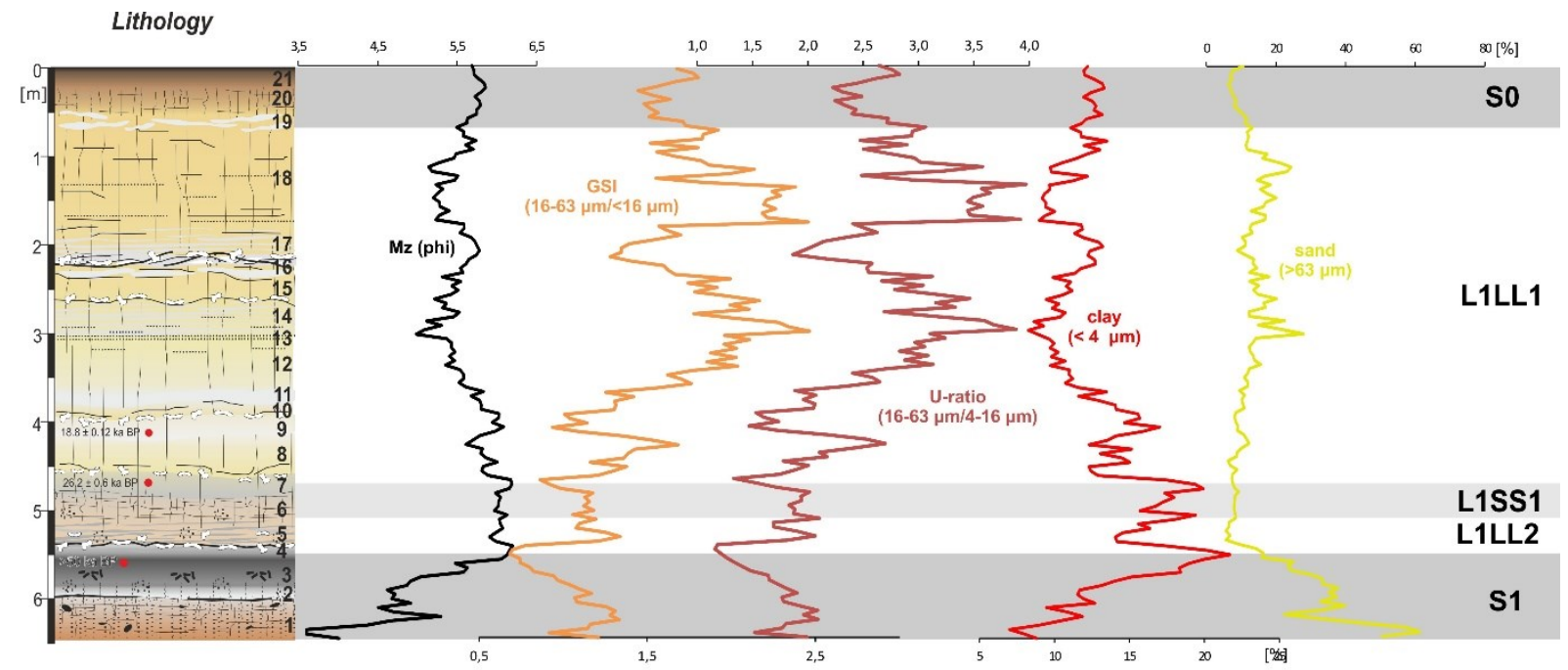

Fig.11. Selected lithological indicators for Zaprężyn profile 


\section{Discussion and conclusions}

For both profiles the analysis of the grain-size variations within the Upper Pleniglacial loess sequences along with detailed stratigraphy, revealed the presence of several short depositional cycles during the time of loess deposition. Relatively coarse-grained loess is alternated with fine-grained loess. Time of high dust influx coincided with severe climate conditions inferred from grain-size variations (Jary, 2007; Antoine et al., 2009). Pye (1995) has proposed a model concerning dust transport which has two modes according to strength in deflating areas and wind speed. First mode concerning transports fine grained silty material $(<20 \mu \mathrm{m})$ at high altitude over very long distances. Second one refers to the transport coarser material over short distances. Taking into account our results, the both analysis loess records match the second model as coarse sand material has been blown from the nearby valleys: from Odra river valley to Zaprężyn and from Oława river valley to Biały Kościól. The similar interpretation is given by Smalley et al. (2009) and Badura et al. (2013) suggesting the valleys of big rivers as a potential source area of coarse material for loess sequence.

The grain-size indexes vary between 0,5 and 2,5. In these records, high values of GSI, related to strong wind speed, are associated with loess units, whereas low GSI values, corresponding to low wind activity, are linked to the occurrence of soils, expressed as boreal soils or gley horizons (Rousseau, 2007). These results are similar to GSI values from main European loess profiles (Antoine et al., 2002, 2013). A similar U-ratio was also applied to a European loess sequence to show rapid changes and high-resolution correlations with other indicators (Vandenberghe et al., 1998).

Both the grain-size distribution and grain size indicators of loess sediments reflects some variations of the climate conditions at the time of loess sedimentation. There are some markers and similarities which can be used for correlation of these sections. However, generally coarsergrain sizes and even sands insert in the Zaprężyn loess section can be the evidence of short episodes of strong winds or even sand storms during the loess sedimentation (Fig.11). Analysis of particle size distributions and indicators shows that the fraction of coarse silt usually rises systematically towards the upper part of loesssoil sequence. That may indirectly indicate the increasing level of climate continentalization and the increasing rate of accumulation of loess due to greater availability and proximity to source areas. Periods of fine-grained loess accumulation and development of weak pedogenic gley horizons, marked by relatively low values of magnetic susceptibility, represent warmer episodes.

The Zaprężyn is the northernmost loess profile in this region situated only ca $70 \mathrm{~km}$ away from the maximum extent of thelast glaciation. The distance between these two profiles is about $60 \mathrm{~km}$. Both loess-soil sequences are composed of interfluve and slope loess facies and consist of five lithopedostratigraphic units developed during the Late Pleistocene and Holocene. There are almost no L1LL2 loess unit in the Zaprężyn section unlike to the Biały Kościół profile with ca 1,5 m L1LL2 unit. Also, the difference in development of soil L1SS1 can be observed: L1SS1 soil unit in Biały Kościół is much better developed than in Zaprężyn. Well-developed periglacial features, as well as several distinct erosional levels noted in the Zaprężyn sequence, suggest extreme and harsh climate conditions in this area during the loess sedimentation. By analyzing and comparing these profiles due to their lithological properties, it can be stated that the gradient of climate change in SW Poland was much tapered during the last glacial maximum. 


\section{References}

Alexandrowicz S.W., Ciszek D. (1998) Late Weichselian and Holocene development of the small valleys in the SE part of the Niemcza Hills, Sudetic Foreland, southwestern Poland. Geologia Sudetica 31, 213-220.

Antoine P., Rousseau D.D., Hatté C., Zöller L., Lang A., Fontugne M., Moine O. (2002) Événements éoliens rapides en contexte loessique: l'exemple de la séquence du Pléniglaciaire supérieur weichselien de Nussloch (Vallée du Rhin-Allemagne). Quaternaire 13, 3-4, 199-208.

Antoine P., Rousseau D.D., Moine O., Kunesch S., Hatte C., Lang A., Tissoux H., Zöller L. (2009) Rapid and cyclic aeolian deposition during the Last Glacial in European loess: a high-resolution record from Nussloch, Germany. Quaternary Science Reviews 28, 2955-2973.

Antoine, P., Rousseau, D.D., Degeai, J.P., Moine, O., Lagroix, F., Kreutzer, S., Fuchs, M., Hatté, C., Gauthier, C., Svoboda, J., Lisá, L. (2013) Highresolution record of the environmental response to climatic variations during the Last Interglacial-Glacial cycle in Central Europe: the loess-palaeosol sequence of Dolní Vestonice (Czech Republic). Quaternary Science Reviews 67, 17-38.

Badura J., Jary Z., Smalley I. (2013) Sources of loess material for deposits in Poland and parts of Central Europe: The lost big river. Quaternary International 296, 15-22. http://dx.doi.org/10.1016/j.quaint.2012.06. 019.

Behr J. (1921) Geologische Karte von. Preussen u. benachbarten Bundesstaaten, Blatt Strehlen, Preuss. Geol. Landesamt, Berlin.

Cegła J. (1965) Porównanie utworów pyłowych kotlin karpackich $\mathrm{z}$ lessami Polski (On origin of the Quaternary silts in the Carpathian Mountains). Annales UMCS, sec. B, XVIII, 69-116.

Cegła J. (1972) Sedymentacja lessów Polski (Loess Sedimentation in Poland). Acta Universitatis Wratislaviensis 168, Studia Geograficzne, 17.

Ciszek D. (1997) Uwagi o sedymentacji lessów na Wzgórzach Niemczańskich i w Kotlinie Kłodzkiej (Notes on the loess sedimentation in the Niemczańskie Hillsand in the Kłodzko Basin), [In:] D. Krzyszkowski and B. Przybylski (ed.), Problems of central polish glaciations in south-west Poland, Przewodnik IV Konferencji Stratygrafia Plejstocenu Polski, Wrocław, 161-162.

Ciszek D., Jary Z., Kida J., Karamanski P. (2001) Profil lessowy w Białym Kościele (Wzgórza Niemczańsko-Strzelińskie). [In:] Jary Z., Kida J., (ed), Osady plejstocenskie przedpola Sudetów. XI Seminarium „Korelacja stratygraficzna lessów i utworów lodowcowych Polski i Ukrainy", Wrocław-Jarnołtówek 23-28.IX.2001, Instytut Geograficzny Uniwersytetu Wrocławskiego, 58-60.

Czajka W. (1931) Der Schlesische Landrücken. Veröff. Schles. Ges. Erdk. 11, 26-57.

Chlebowski R., Ciszek D., Jary Z., Kida J. (2004a) Mineralogical characteristics of loesses from Biały Kościół (NiemczańskoStrzelińskie Hills) based on heavy minerals analysis. [In:] Polskie Towarzystwo Mineralogiczne Prace Specjalne, z. 24, Uniwersytet Śląski, 111-114.

Chlebowski R., Ciszek D., Jary Z., Kida J. (2004b) Charakterystyka mineralogiczna lessów z wybranych profilów przedpola Sudetów w oparciu o analizę minerałów ciężkich. [In:] Jary Z. (ed.), 2004, Record of climatic changes In less successions, 4th Loess Seminar, Strzelin 13-16 october 2004, Institute of Geography and Regional Development, University of Wrocław, 2227. 
Dwucet K. (1993) Charakterystyka stopnia agregatyzacji lessów w Polsce. Geographia. Studia et Dissertationes 18, 30-48.

Dwucet K. (1999) Litogeneza górnego lessu vistulianskiego na Wyżynach Polskich i na Nizinie Śląskiej. Prace Naukowe Uniwersytetu Śląskiego w Katowicach 1792, $163 \mathrm{pp}$.

Dylik J. (1952) Głazy rzeźbione przez wiatr i utwory podobne do lessu w środkowej Polsce. Biuletyn PIG 67.

Dylik J. (1954) Zagadnienie genezy lessu w Polsce. Biuletyn Peryglacjalny 1, 19-31.

Folk L.R., Ward W.C. (1957) Brazos River bar: a study in the significance of grain size parameters. Journal of Sedimentary Petrology 27(1), 3-26.

Fedorowicz S., Ciszek D., Jary Z. (2004) Wiek TL próbek z profili lessowych: Biały Kościól, Dankowice, Księginice Małe i Zaprężyn. [In:] Jary Z. (ed.), 2004, Record of climatic changes In less successions, 4th Loess Seminar, Strzelin 13-16 october 2004, Institute of Geography and Regional Development, University of Wrocław, 3336.

Fedorowicz S. (2005) Korelacja dat TL i OSL próbek z czterech profili lessowych Polski SE i SW. Przegląd Geologiczny 53/11, 1047-1050.

Fedorowicz S. (2006) Metodyczne aspekty luminescencyjnego oznaczania wieku osadów neoplejstoceńskich Europy Środkowej. Wydawnictwo Uniwersytetu Gdańskiego, 156.

Jahn A., Szczepankiewicz S. (1967) Osady i formy czwartorzędowe Sudetów i ich przedpola. [In:] R. Galon i J. Dylik (ed.) Czwartorzęd Polski, PWN, Warszawa, 397-430.

Jary Z. (1991a) Erozja wąwozowa na Wysoczyźnie Głubczyckiej. Acta Universitatis Wratislaviensis 1237, Prace Instytutu Geografii A(6), 131-151.
Jary Z. (1991b) Profil utworów lessowych w Trzebnicy k. Wrocławia. [In:] H. Maruszczak (ed.), Podstawowe profile lessów w Polsce, UMCS, Lublin, B, 196200.

Jary Z. (1993) Stanowisko Lessowe w Trzebnicy. [In:] Lessy Płaskowyżu Głubczyckiego i Wzgórz Trzebnickich, Przewodnik II Seminarium Lessowego, Wrocław-Jakubowice 21-23 X 1993 r., Instytut Geografii Uniwersytetu Wrocławskiego, 31-39.

Jary Z. (1996) Chronostratygrafia oraz warunki sedymentacji lessów południowo zachodniej Polski na przykładzie Płaskowyżu Głubczyckiego i Wzgórz Trzebnickich (Chronostratigraphy and the course of loess sedimentation in SW Poland on the example of the Glubczyce Upland and Trzebnica Hills). Acta Universitatis Wratislaviensis, Studia Geograficzne 63, 103 pp.

Jary Z. (2002) Periglacial structures in the last interglacial-glacial loess sequences in SW Poland. [In:] Shaping the earth - A Quaternary perspective, Programs with Abstracts, XVI INQUA Congress (Reno, Nevada, July 23-30, 2003), 190.

Jary Z. (2004) Zróżnicowanie uziarnienia lessów młodszych jako wskaźnik zmian klimatu. [In:] Jary Z. (ed.), Record of climatic changes in less successions, 4th Loess Seminar, Strzelin 13-16 October 2004, Institute of Geography and Regional Development, University of Wrocław, 5052.

Jary Z. (2007) Zapis zmian klimatu w górnoplejstoceńskich sekwencjach lessowo-glebowych w Polsce i w zachodniej części Ukrainy (Record of Climate Changes in Upper Pleistocene loess-soil sequences in Poland and western part of Ukraine). Rozprawy Naukowe Instytutu Geografii i Rozwoju Regionalnego Uniwersytetu Wrocławskiego 1, Wrocław, 136 pp. 
Jary Z. (2010) Loess-soil sequences as a source of climatic proxies: an example from SW Poland. Geologija 52, 1-4 (69-72), 40-45.

Jary Z., Ciszek D. (2004) Odsłonięcie lessów w Zapreżynie na Wzgórzach Trzebnickich. [In:] Jary Z. (ed.), Record of climatic changes in less successions, 4th Loess Seminar, Strzelin 13-16 October 2004, Institute of Geography and Regional Development, University of Wrocław, 108112.

Jary Z., Krawczyk M., Raczyk J., Ryzner K. (2016) Loess in Lower Silesia. [In:] Faust D. and Heller K. (eds.), Erkundungen in Sachsen und Schlesien: quartäre sedimente im landschaftsgenetischen kontext. Geozon Science Media 2016, 57-73.

Jary Z., Krzyszkowski D. (1990) Charakterystyka geomorfologiczna rejonu stanowiska neolitycznego w Strachowie. Śląskie Sprawozdania Archeologiczne 31, 77-84.

Jary Z., Krzyszkowski D. (1995) Stratigraphy, properties and origin of loess in Trzebnica Brickyard, Southwestern Poland. Acta Universitatis Wratislaviensis 1702, Prace Instytutu Geografii A7, 63-83.

Jersak J. (1965) Stratygrafia i geneza lessów okolic Kunowa. Acta Geographica Lodziensia 20, $121 \mathrm{pp}$.

Jersak J. (1973) Litologia i stratygrafia lessu wyżyn południowej Polski (Lithology and stratigraphy of the loess on the Southern Polish Uplands. Acta Geographica Lodziensia 32, 139 pp.

Kida J. (1983) Lessy Opolszczyzny. Archiwum Instytutu Geografii i Rozwoju Regionalnego Uniwersytetu Wrocławskiego, maszynopis pracy doktorskiej, $311 \mathrm{pp}$.

Komar M., Jary Z., Ciszek D., Kida J. (2004) Palynology of aeolian sediments of the Late Pleistocene at Biały Kościól, Niemcza-Strzelin Hills (preliminary results). [In:] Jary Z. (red.), Record of climatic changes In less successions, 4th
Loess Seminar, Strzelin 13-16 October 2004, Institute of Geography and Regional Development, University of Wrocław, 6364.

Kondracki J. (1981) Geografia Fizyczna Polski. PWN, p. 467.

Kukla G.J., An Z.S. (1989) Loess stratigraphy in central China. Palaeogeography, Palaeoclimatology, Palaeoecology 72, 203225.

Liu T.S. (1985) Loess and the Environment. China Ocean Press, 251 pp.

Liu T.S., Ding Z.L., Chen M.Y., An Z.S. (1989) The global surface energy system and the geological role of wind stress. Quaternary International 2, 43-54.

Marković S.B., Stevens T., Kukla G.J., Hambach U., Fitzsimmons K.E., Gibbard Ph., Buggle B., Zech M., Guo Z., Hao Q., Wu H., O'Hara-Dhand K., Smalley I.J., Ujvari G., Sumegi P., Timar-Gabor A., Veres D., Sirocko F., Vasiljević D.A., Jary Z., Svensson A., Jović V., Lehmkuh F., Kovacs J., Svircev Z. (2015) Danube loess stratigraphy - Towards a pan-European loess stratigraphic model. Earth Science Reviews 148, 228-258. http://dx.doi.org/10.1016/j.earscirev.2015.0 6.005

Maruszczak H. (2001) Schemat stratygrafii lessów i gleb sródlessowych w Polsce (Stratigraphic scheme of loesses and paleosols in Poland). [In:] Maruszczak H. (ed.), Podstawowe profile lessów w Polsce II (Main section of loesses in Poland II), Wydawnictwo UMCS, Lublin, 17-29.

Maruszczak H. (1991) Zróżnicowanie stratygraficzne lessów polskich. [In:] Maruszczak H. (ed.), Podstawowe profile lessów w Polsce, Wyd. UMCS, Lublin, A, 13-35.

Meister E. (1935) Blatt Weise. Erläuterungen zur Geol. Karte von Preussen und benachbarten deutschen Ländern, Preus. Geol. Landesanstalt, Berlin, ss. 51. 
Moska P., Adamiec G., Jary Z. (2011) OSL Dating and lithological characteristics of Loess deposits from Biały Kościół. Geochronometria 38(2), 162-171.

Moska P., Adamiec G., Jary Z. (2012) High resolution dating of loess profile from Biały Kościól, south-west Poland. Quaternary Geochronology 10, 87-93.

Myślińska E. (2001) Grunty organiczne i laboratoryjne metody ich badania. Warszawa, Wydawnictwo Naukowe PWN.

Pye K. (1995) The nature, origin and accumulation of loess. Quaternary Science Reviews 14, 653-667.

Raczkowski W. (1960) Less w okolicach Henrykowa na Dolnym Śląsku. Biuletyn Peryglacjalny 7, 95-111.

Raczkowski W. (1969) Lessy i utwory pylaste Przedgórza Sudeckiego. Archiwum Instytutu Geografii i Rozwoju Regionalnego Uniwersytetu Wrocławskiego, maszynopis pracy doktorskiej, $149 \mathrm{pp}$.

Raczkowski W. (1976) Niektóre problemy genezy lessów Przedgórza Sudeckiego. Biuletyn Instytutu Geologicznego 297, 329-343.

Rokicki J. (1952a) Warunki występowania utworów pyłowych i lessów na Dolnym Śląsku. Annales UMCS B, 5, 53-95.

Rokicki J. (1952b) Lessy i utwory pyłowe Wzgórz Trzebnickich. Biuletyn Instytutu Geologicznego 65, 479-512.

Rousseau D.D., Antoine P., Hatté C., Lang A., Zöller L., Fontugne M., Ben Othman D., Luck J.M., Moine O., Labonne M., Bentaleb I., Jolly D. (2002) Abrupt millennial climatic changes from Nussloch (Germany) Upper Weichselian eolian records during the last glaciation. Quaternary Science Reviews 21, 15771582.

Rousseau D.D., Sima A., Antoine P., Hatté C., Lang A., Zöller L. (2007) Link between European and North-Atlantic abrupt climate changes over the last glaciation.
Geophysical Research Letter 34 (L22713), 1029/2007/GL031716.

Schwarzbach M. (1942) Das Diluvium Schlesiens, N. Jhrb. Miner. Geol. Paläont. 86, 189-246.

Smalley I., O'Hara-Dhand K., Wint J., Machalett B., Jary Z., Jefferson I. (2009) Rivers and loess: The significance of long river transportation in the complex eventsequence approach to loess deposit formation. Quaternary International 198, 7-18. doi:10.1016/j.quaint.2008.06.009

Sobik M. (2005) Klimat. [In:] Fabiszewski J. (ed), Przyroda Dolnego Śląska. PAN Wrocław, 39-57.

Szponar A. (1998) Czwartorzęd południowowschodniej części Wzgórz Trzebnickich. [In:] Wybrane problemy czwartorzędu południowo-zachodniej Polski (Selected problems of the Quaternary of SouthWestern Poland). Acta Universitatis Wratislaviensis 2083, Studia Geograficzne 71, 6-18.

Śnieszko Z. (1995) Geologiczne tło stanowiska dolnopaleolitycznego w Trzebnicy. Śląskie Sprawozdania Archeologiczne 36, 19-34.

Tietze O. (1910) Die geologischen Verhaltnisse der Umgegend von Breslau. Jahrb. Preuss. Geol. Landesanstalt 31, 258298.

Tietze O. (1919) Blatt Nimptsch. Erläuterungen zur Geol. Karte von. Preussen $u$. benachbarten Bundesstaaten, Preuss. Geol. Landesamt, Berlin.

Traczyk A. (1996) Wykształcenie i wiek osadów stokowych $\mathrm{w}$ rejonie stanowiska archeologicznego w Trzebnicy. Acta Universitatis Wratislaviensis 1808, Prace Instytutu Geograficznego A8, 93-104.

Traczyk A. (1999) Zagadnienie rozmieszczenia utworów pyłowych w północnej części Wzgórz Niemczańskich (Przedgórze Sudeckie). [In:] Jary Z. (ed.), Geneza i wiek pokrywowych utworów pylastych południowo-zachodniej Polski, 
III Seminarium Lessowe, WrocławBożków, 8-10.X.1999, 68-72.

Ujvari G., Kok J.F., Varga G., Kovacs J. (2016) The physics of wind-blown loess: Implications for grain size proxy interpretations in Quaternary paleoclimate studies. Earth-Science Reviews 154, $247-$ 278.

Vandenberghe J., Mücher H.J., Roebroeks W., Gemke D. (1985) Lithostratigraphy and palaeoenvironment of the Pleistocene deposits at Maastricht-Belvedere, Southern Limburg, The Netherlands. Meded. Rijks Geol. Dienst, Nieuwe Ser. (Neth.) 39, 718.

Vandenberghe J., An Z.S., Nugteren G., Lu H., van Huissteden J. (1997) New absolute time scale for the Quaternary climate in the Chinese loess region by grain-size analysis. Geology 25, 35-38.

Vandenberghe J., Huijzer A.S., Mücher H.J., Laan W. (1998) Short climatic oscillations in a western European loess sequence Kesselt, Belgium. Journal of Quaternary Science 13, 471-485.

Vandenberghe J., Nugteren G. (2001) Rapid climatic changes recorded in loess successions. Global and Planetary Change 28, 1-9.

Walczak W. (1951) Sprawozdanie z badań nad stratygrafią i morfologią utworów plejstoceńskich okolicy Trzebnicy. Czasopismo Geograficzne 21/22, 434-438. 